\title{
Is the Astragalar Index a Valid Character for the Study of Giraffid Phylogeny?
}

\begin{abstract}
Rios $\mathbf{M}^{*}$
Department of Paleobiology, University of Valencia, Spain
\end{abstract}

*Corresponding author: Maria Rios, Department of Paleobiology, University of Valencia, Spain, C/ José Gutiérrez Abascal, 2, 28006 Madrid, Spain, Tel: +34 676371424; Email: maria.rios.iba@gmail.com

\section{Research Article \\ Volume 1 Issue 1}

Received Date: September 26, 2018

Published Date: October 05, 2018

\section{Abstract}

Astragali are one of the most recovered skeletal elements as it can be seen in several of the most complete giraffid fossil collections. Even in sites where all the skeletal elements are well represented they tend to be one of the more abundant, making them a very valuable element for the identification and study of the taxa they belong to. Recent studies have shed light on the phylogenetic importance of the morphological features of the astragalus but not valuable quantitative parameters have been described yet. In this study we analyze several giraffid astragal biometric parameters to find out its phylogenetic relevance, in cases were the preservation does not allow an accurate morphological description.

Keywords: Astragalus; Giraffidae; Vertebrate; Mammalia; Morphology; Phylogeny

\section{Introduction}

The Giraffidae is a relict family with only two extant genera: Giraffa [1] and Okapia [2] in the past was more abundant and diversified, with more than 40 taxa spanning the past 20 million years (since the beginning of the early Miocene) [3-6]. Nevertheless, until recently only a few studies approached the description of their phylogenetic relationships [4,5], due to the lack of appropriate materials to build a solid character matrix and the scarcity of complete fossil giraffid skulls as well as the high intra- and interspecific variability of most of giraffid teeth $[7,4]$ the postcranial skeleton has probed key to giraffid identification [6,8-10].

Giraffid astragali are part of the hind limb, and together with the cubonavicular the calcaneus and the ento-ectomeso cuneiform form the articulation of the tibia with the metatarsal III-IV [11]. As in the rest of artiodactyls, the astragalus of giraffids has a double pulley structure [6] that dorsally articulate with the distal tibia, plantarly with the cubonavicular and laterally to the calcaneus. The recent remarkable study on their morphology by Solounias, et al. [10] pointed out the importance of the study of tarsal morphology to make accurate identifications in giraffids as each giraffid astragalus exhibits a unique combination of anatomical characteristics. They also describe highly valuable morphological features that are very helpful to phylogeny and reinforce previously established phylogenetic relationships.

However in some cases the preservation of fossils does not allow for accurate anatomical descriptions and some important features are lost, and given the abundance of astragali in giraffid collections internationally we want to analyze the biometric parameters of several giraffid taxa in order to assess their phylogenetic relevance, since previous studies have probed biometrical features of high value [9].

\section{Materials and Methods}

The giraffid astragali analyzed in this work comes from the fossil collections curated by the MNCN-CSIC (Madrid, Spain), the Institut Català de Paleontologia 


\section{International Journal of Paleobiology \& Paleontology}

(Sabadell, Spain), the Museo de Geologia de la Universidad de Valencia (Burjasot, Spain); the AMNH (New York, USA), the NHM (London, UK) and the MNHN (Paris, France).

They include the fossil giraffid taxa from the early to midMiocene Canthumeryx sirtensis from Libya; Injanatherium arabicum from Saudi Arabia; Giraffokeryx punjabiensis from Pakistan and India and Giraffokeryx primaevus from Kenya. From the late Miocene of the Iberian Peninsula Decennatherium pachecoi, Decennatherium rex, and Birgerbohlinia schaubi. From the early Turolian to late Pliocene of Greek-Iranian region Samotherium major, Samotherium boissieri, Palaeotragus rouenii, Bohlinia attica. Helladotherium duvernoyi, Alcicephalus neumayri and Palaeotragus coelophrys. Also from the same collections comes the data of the Chinese Schansitherium tafeli, Honanotherium schlosseri and Samotherium sinense from the late Miocene and early Pliocene of China. Finally, from the late Miocene of India and Pakistan Bramatherium perimense and Bramatherium megacephalum as well as the early Pleistocene Sivatherium giganteum and Giraffa jumae Turkey and Kenya; as well as the extant giraffids Giraffa camelopardalis and Okapia johnstoni from the collections of comparative anatomy of the MNCN-CSIC (Madrid, Spain) and the AMNH (New York, USA). Additional information on the specimens from this study is included in Appendix 1 as well as additional biometrical information that come from several publications, listed also on Appendix 1.

\section{Measurements}

We follow the set of measurements illustrated in (Figure 1). All were taken with digital calipers and compiled in excel. Due to the extension they can be found on Appendix 1.

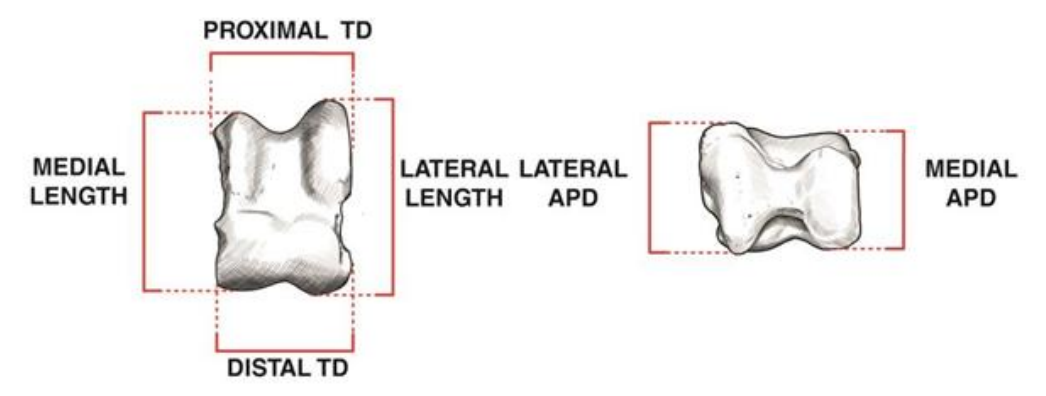

ANTERIOR VIEW

PROXIMAL VIEW

Figure 1: Astragalar measurements defined for this study based on a Decennatherium rex astragalus. Paleoillustration by Rubén Guerrero.

\section{Nomenclature}

We use the terminology of Barone [12] for anatomic nomenclature of the postcranial skeleton.

\section{Institutional / Technical abbreviations}

AMNH, American Museum of Natural History, New York, USA; ICP, Institut Català de Paleontologia- Miquel Crusafont, Barcelona, Spain; MGUV, Museu de Geologia de la Universitat de València; MNCN-CSIC, Museo Nacional de Ciencias Naturales-CSIC, Madrid, Spain; MNHN, Musèum national d'Histoire naturelle, Paris, France; NHM, Natural History Museum, London, UK.

\section{Results}

We analyzed three different Astragalar indexes that recover their biommetric variability and checked for their phylogenetic potential:

(1)Distal transverse diameter/Lateral length*100

(2)Medial anteroposterior diameter/Medial length*100

(3) Medial length / Lateral length*100

The results of the three can be seen in Figures 2-4 and Tables 1-3. 


\section{International Journal of Paleobiology \& Paleontology}

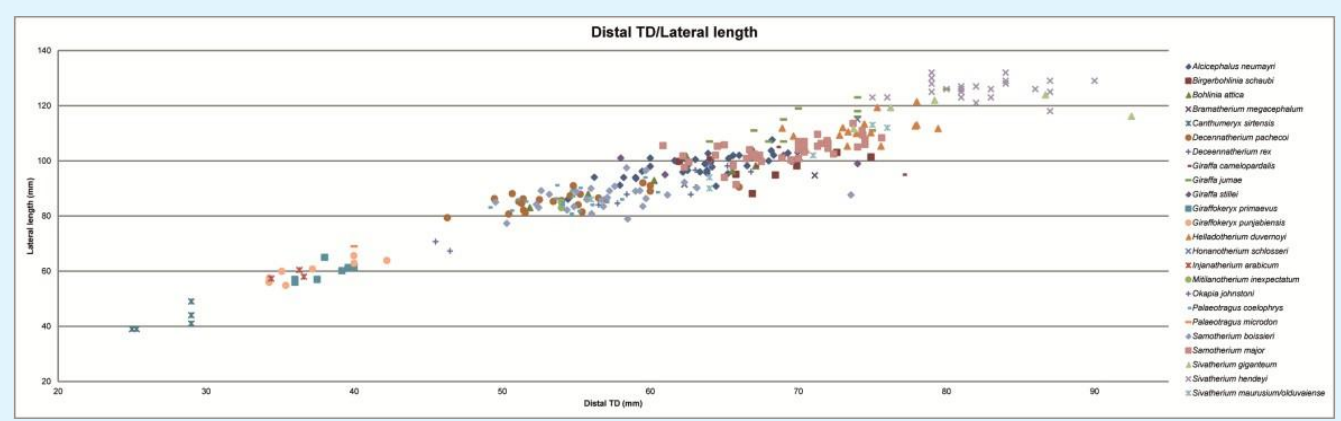

Figure 2: Dispersal plot showing the Index (1) of the giraffid taxa analyzed (measurements in $\mathrm{mm}$.).

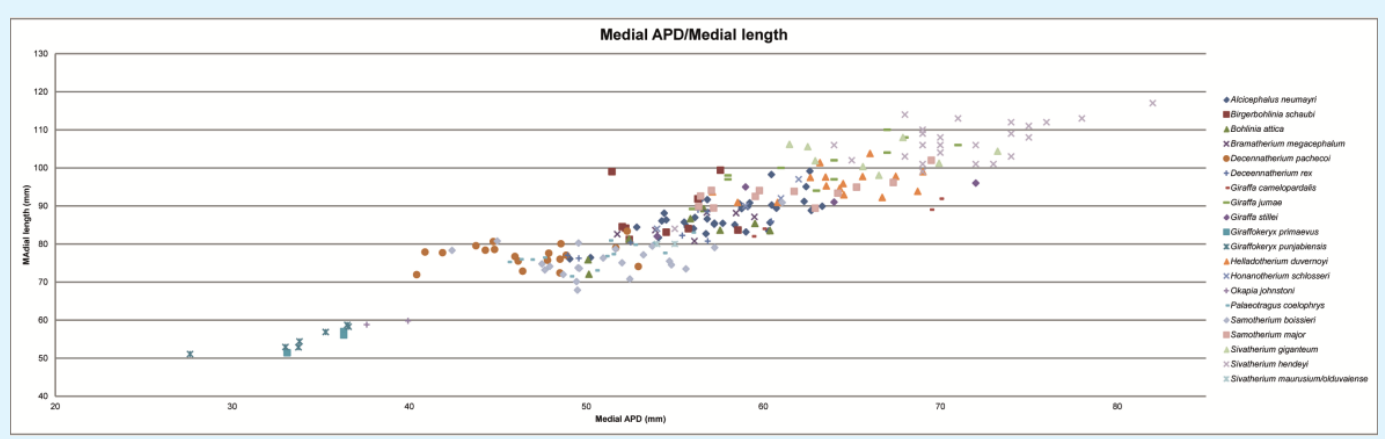

Figure 3: Dispersal plot showing the Index (2) of the giraffid taxa analyzed (measurements in mm.).

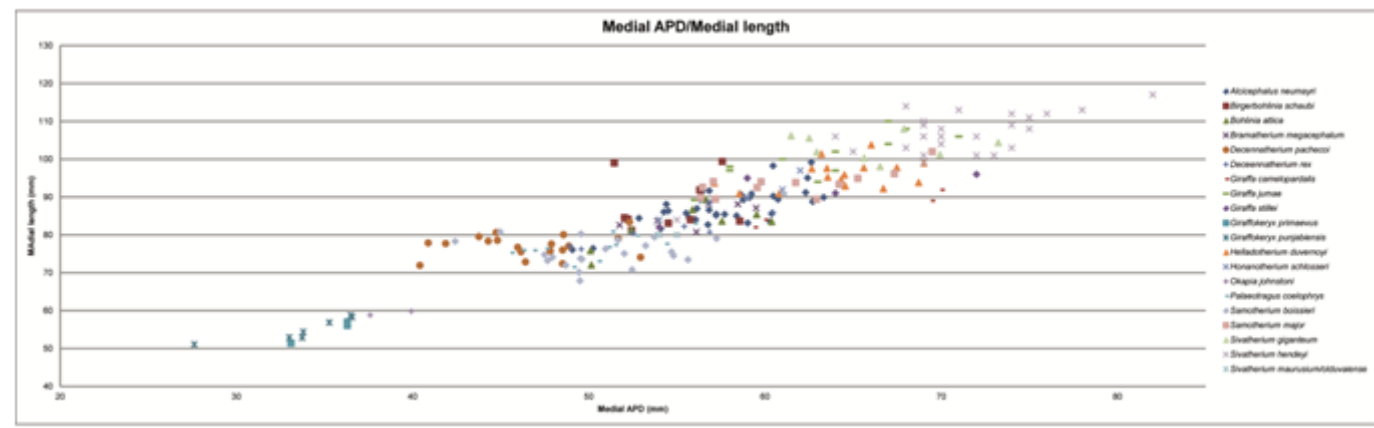

Figure 4: Dispersal plot showing the Index (3) of the giraffid taxa analyzed (measurements in mm.).

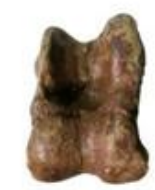

A

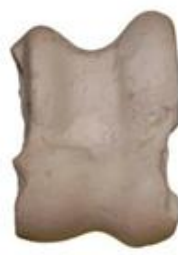

B

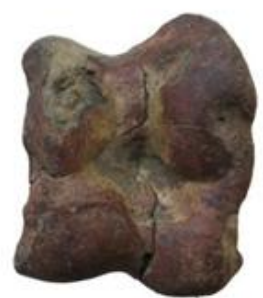

C

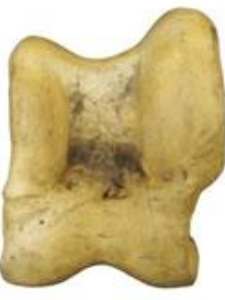

D

Figure 5: Dorsal views of giraffid astragali. A) Giraffokeryx punjabiensis , AMNH-19453; B) Decennatherium rex, BAT10'09-G2-59; C) Sivatherium giganteum, NM OR-16998; D) Giraffa camelopardalis, AM-5354. Scale bar equals 5 mm. 


\section{International Journal of Paleobiology \& Paleontology}

\begin{tabular}{|c|c|c|c|c|c|}
\hline \multirow{2}{*}{ Taxa } & \multicolumn{5}{|c|}{ DISTAL TD/LATERAL LENGTH*100 } \\
\cline { 2 - 5 } & Minimum & Mean & Maximum & Standard Deviation & Total N \\
\hline Alcicephalus neumayri & 59,406 & 64,657 & 70,946 & 2,764 & 43 \\
\hline Birgerbohlinia schaubi & 62,125 & 70,027 & 75,916 & 4,191 & 13 \\
\hline Bohlinia attica & 61,402 & 64,786 & 68,378 & 2,901 & 10 \\
\hline Bramatherium megacephalum & 68,125 & 70,427 & 75,074 & 3,212 & 7 \\
\hline Canthumeryx sirtensis & 59,184 & 64,960 & 70,732 & 4,133 & 5 \\
\hline Decennatherium pachecoi & 57,330 & 63,076 & 72,928 & 3,690 & 32 \\
\hline Decennatherium rex & 65,232 & 68,051 & 71,458 & 2,085 & 8 \\
\hline Giraffa camelopardalis & 65,495 & 69,481 & 73,429 & 3,368 & 13 \\
\hline Giraffa jumae & 58,824 & 62,573 & 67,568 & 2,754 & 11 \\
\hline Giraffa stillei & 62,366 & 66,924 & 70,000 & 3,260 & 8 \\
\hline Giraffokeryx primaevus & 58,462 & 63,770 & 65,789 & 2,478 & 8 \\
\hline Giraffokeryx punjabiensis & 58,585 & 61,957 & 66,067 & 2,547 & 23 \\
\hline Helladotherium duvernoyi & 61,631 & 66,910 & 71,776 & 2,865 & 5 \\
\hline Honanotherium schlosseri & 64,348 & 64,497 & 64,646 &, 211 & 3 \\
\hline Injanatherium arabicum & 60,035 & 61,079 & 63,103 & 1,753 & 6 \\
\hline Mitilanotherium inexpectatum & 63529 & 64,295 & 65,060 & 1,082 & 2 \\
\hline Okapia johnstoni & 64,356 & 66,713 & 69,070 & 3,333 & 22 \\
\hline Palaeotragus coelophrys & 58,837 & 63,450 & 68,179 & 3,223 & 2 \\
\hline Palaeotragus microdon & 57,971 & 57,971 & 57,971 & & 2 \\
\hline Palaeotragus rouenii & 61,619 & 62,782 & 63,946 & 1,645 & 35 \\
\hline Samotherium boissieri & 58,267 & 65,936 & 83,932 & 5,206 & 52 \\
\hline Samotherium major & 57,671 & 66,413 & 71,991 & 2,932 & 10 \\
\hline Sivatherium giganteum & 63,930 & 68,910 & 79,632 & 6,413 & 3,303 \\
\hline Sivatherium hendeyi & 59,848 & 65,311 & 73,729 & 2,157 & 9 \\
\hline Sivatherium maurusium/olduvaiense & 65,116 & 68,025 & 71,111 & & \\
\hline
\end{tabular}

Table 1: Descriptive parameters of the Astragalar Index (1).

\begin{tabular}{|c|c|c|c|c|c|}
\hline \multirow{2}{*}{ Taxa } & \multicolumn{5}{|c|}{ MEDIAL APD/MEDIAL LENGTH*100 } \\
\cline { 2 - 6 } & Minimum & Mean & Maximum & Standard Deviation & Total N \\
\hline Alcicephalus neumayri & 100,324 & 104,922 & 114,190 & 3,666 & 43 \\
\hline Birgerbohlinia schaubi & 85,816 & 95,854 & 108,866 & 5,897 & 13 \\
\hline Bohlinia attica & 103,157 & 108,110 & 116,902 & 5,306 & 10 \\
\hline Bramatherium megacephalum & 95,887 & 100,045 & 103,785 & 3,753 & 7 \\
\hline Decennatherium pachecoi & 93,155 & 102,074 & 112,428 & 5,805 & 32 \\
\hline Decennatherium rex & 100,159 & 105,501 & 111,819 & 4,615 & 8 \\
\hline Giraffa camelopardalis & 116,390 & 116,390 & 116,390 &. & 6 \\
\hline Giraffokeryx primaevus & 104,747 & 108,814 & 115,863 & 6,129 & 8 \\
\hline Giraffokeryx punjabiensis & 91,245 & 96,476 & 101,696 & 4,728 & 23 \\
\hline Helladotherium duvernoyi & 91,277 & 109,495 & 116,086 & 6,378 & 2 \\
\hline Okapia johnstoni & 108,094 & 108,495 & 108,094 &. & 22 \\
\hline Palaeotragus coelophrys & 104,107 & 106,348 & 111,812 & 2,321 & 35 \\
\hline Samotherium boissieri & 89,244 & 103,162 & 120,986 & 9,433 & 52 \\
\hline Samotherium major & 94,848 & 102,290 & 113,889 & 5,637 & \\
\hline Sivatherium giganteum & 95,640 & 104,098 & 112,500 & 5,504 & 9 \\
\hline Sivatherium maurusium/olduvaiense & 112,698 & 113,380 & 114,063 &, 965 & 9 \\
\hline
\end{tabular}

Table 2: Descriptive parameters of the Astragalar Index (2). 


\section{International Journal of Paleobiology \& Paleontology}

\begin{tabular}{|c|c|c|c|c|c|}
\hline \multirow{2}{*}{ Taxa } & \multicolumn{5}{|c|}{ MEDIAL LENGTH/LATERAL LENGTH*100 } \\
\hline & Minimum & Mean & Maximum & Standard Deviation & Total N \\
\hline Alcicephalus neumayri & 83,973 & 88,795 & 93,694 & 2,230 & 43 \\
\hline Birgerbohlinia schaubi & 81,653 & 87,571 & 99,258 & 5,976 & 13 \\
\hline Bohlinia attica & 86,288 & 87,237 & 88,264 & 751 & 10 \\
\hline Bramatherium megacephalum & 85,251 & 87,279 & 90,290 & 2,471 & 7 \\
\hline Decennatherium pachecoi & 84,289 & 90,886 & 98,098 & 3,546 & 32 \\
\hline Decennatherium rex & 89,495 & 90,986 & 91,970 & ,759 & 8 \\
\hline Giraffa camelopardalis & 85,016 & 86,142 & 87,524 & 1,063 & 6 \\
\hline Giraffa jumae & 84,127 & 88,847 & 92,437 & 2,612 & 13 \\
\hline Giraffa stillei & 83,871 & 88,184 & 95,960 & 3,994 & 11 \\
\hline Giraffokeryx primaevus & 90,175 & 91,737 & 93,157 & 1,362 & 8 \\
\hline Giraffokeryx punjabiensis & 86,982 & 91,150 & 99,198 & 3,706 & 8 \\
\hline Helladotherium duvernoyi & 81,958 & 86,141 & 90,918 & 2,377 & 23 \\
\hline Honanotherium schlosseri & 84,348 & 84,598 & 84,848 & ,354 & 5 \\
\hline Injanatherium arabicum & 87,417 & 90,605 & 93,019 & 2,880 & 3 \\
\hline Mitilanotherium inexpectatum & 94,118 & 94,118 & 94,118 & . & 6 \\
\hline Okapia johnstoni & 83,168 & 86,033 & 88,897 & 4,051 & 2 \\
\hline Palaeotragus coelophrys & 81,025 & 88,377 & 93,135 & 3,617 & 22 \\
\hline Palaeotragus rouenii & 88,435 & 88,435 & 88,435 & . & 2 \\
\hline Samotherium boissieri & 84,077 & 88,935 & 103,720 & 3,964 & 35 \\
\hline Samotherium major & 86,216 & 89,663 & 94,489 & 1,879 & 52 \\
\hline Sivatherium giganteum & 82,212 & 86,026 & 89,909 & 3,677 & 10 \\
\hline Sivatherium hendeyi & 80,303 & 85,711 & 90,909 & 2,914 & 38 \\
\hline Sivatherium maurusium/olduvaiense & 85,106 & 87,930 & 93,023 & 3,164 & 9 \\
\hline
\end{tabular}

Table 3: Descriptive parameters of the Astragalar Index (3).

\section{Discussion}

Despite the Giraffidae being a relict family with only two extant genera it shows an extremely high past diversity with a wide arrange of shape and forms between all present and extinct giraffids [7,5]. This diversity is reflected in the giraffid astragalus through its morphology and proportions [10].

Given that Past studies have probed that biometrical features in metacarpals III-IV and metatarsals III-IV in giraffids are useful for giraffid identification [9] we found interesting to research Astragalus biometrical features as they have been exhaustively anatomically described [10] and are usually found in fossil sites, if not in pristine conditions at least preserving is overall form and size (they are a strong compact bone).

We took absolute standardized measurements and analyzed the astragalus shape with biometrical indexes and as we can see in the results section (Figures 2-4, Tables 1-3) some of the indexes tend to give more phylogenetic information about the giraffid taxa analyzed.
Index (1), which relates the distal transverse diameter to the lateral length, giving us information about the overall shape, it being squarer or more rectangular, probes to be a reliable biometrical feature. As we see in figure 2, the most primitive taxa as Canthumeryx sirtensis, Giraffokeryx punjabiensis, Injanatherium arabicum and Giraffokeryx primaevus, have smaller overall size and smaller index (1) value (the smallest being of 57, Table 1, Figure 5), meaning a more rectangular overall shape, whereas later and more derived taxa as Samotherium boissieri, Samotherium major and Helladotherium duvernoyi show a higher size and higher value indexes with the highest mean values being those of being the very large fossil taxa Decennatherium rex, Sivatherium maurusium/olduvaiense, Bramatherium megacephalum, Birgerbohlinia schaubi and Sivatherium giganteum which are all part of the Samotheriinae-Sivatheriinae clade and have robust limbs and the extant Giraffa Camelopardalis, the largest of the Giraffa genus and the more robust of them, and which shows some the most square-shaped astragali with index (1) values of over 73 (Table 1, Figure $5)$. 


\section{International Journal of Paleobiology \& Paleontology}

Index (2) which relates the medial anteroposterior diameter with the medial length, giving information on the shape of the medial side, or the medial thickness of the astragalus (Figure 3, Table 2). Figure 3 also shows the more primitive and older taxa on the left, as Giraffokeryx punjabiensis, as they have smaller overall size and a lower value of index (2), though most of the taxa plot together in the middle of the graph with similar index (2) values, making it hard to differentiate between each other and making it less useful. It is useful two for the large Sivatherium maurusium/olduvaiense and Giraffa camelopardalis which share means above 110, making them have greater thickness related to the height medially and easier to identify.

Index (3), which relates medial length to lateral length (Figure 4, Table 3) shows the difference in size between the two sides of the astragalus. AS in the indexes mentioned above, the graph separates very well the smaller and more primitive giraffids, as well as the largest ones but renders difficult to use for the identification of most giraffid taxa. Most giraffids also share a similar index (3) values (between 85-90) with only Injanatherium arabicum, Mitilanotherium inexpectatum, Decennatherium pachecoi, Decennatherium rex, Giraffokeryx punjabiensis, and Giraffokeryx primaevus, showing values above 90, meaning their lateral ridge of the trochlea is larger in relation to the medial dirge of the trochlea than in other giraffids.

\section{Conclusions}

Each giraffid astragalus exhibits a unique combination of biometrical characteristics and biometrical measurements can be very useful to identify giraffid taxa. However, most of late Miocene fossil giraffids fall within the same range of index values, and have overall similar shapes, rendering the use of the astragalar proportions as a tool for phylogenetic studies one to use with caution. That being said, the most derived and the most primitive taxa can be easily biometrically distinguished, so though limited, the use of standardized biometrical features can be of help in developing future phylogenetic character matrixes for the Giraffidae and can be helpful in cases where the state of the fossils don't allow for accurate morphological descriptions.

\section{References}

1. Gray JE (1821) On the natural arrangement of vertebrate animals. London Medical Repository 15: 297-310.
2. Sclater PL (1901) On an apparently new species of Zebra from the Semliki forest. Proccedings of the Zoological Society of London 1: 50-52.

3. Hamilton WR (1978) Fossil Giraffes from the Miocene of Africa and a Revision of the Phylogeny of the Giraffoidea. Philosophical Transactions of the Royal Society of London. Series B, Biological Sciences 283(996): $165-229$.

4. Ríos M, Sánchez IM, Morales J (2016b) Comparative anatomy, phylogeny, and systematics of the Miocene giraffid Decennatherium pachecoi Crusafont, 1952 (Mammalia, Ruminantia, Pecora): State of the art. Journal of Vertebrate Paleontology 36(5): e1187624.

5. Ríos M, Sánchez IM, Morales M (2017) A new giraffid (Mammalia, Ruminantia, Pecora) from the late Miocene of Spain, and the evolution of the sivatheresamothere lineage. PLoS One 12(11): e0185378.

6. Solounias N (2007) Family Giraffidae In: Prothero, SEDRF (Eds.), The Evolution of Artiodactyls. The Johns Hopkins University Press, Baltimore 367: 257277.

7. Harris J M, Solounias N, Geraads D (2010) Giraffoidea. In: Wijrdelin L, (Eds), Cenozoic Mammals of Africa (Chapter 39) University of California Press, pp: 805820.

8. Danowitz M, Domalski R, Solounias N (2015) The cervical anatomy of Samotherium, an intermediatenecked giraffid. Royal Society Open Science 2(11): 150521.

9. Rios M, Danowitz M, Solounias N (2016a) First comprehensive morphological analysis on the metapodials of Giraffidae. Palaeontologia Electronica 19(3): 1-39.

10. Solounias N, Danowitz M (2016) Astragalar Morphology of Selected Giraffidae. PLoS One 11(3): e0151310.

11. Dagg AI (2014) Giraffe: biology, behaviour and conservation: Cambridge University Press.

12. Barone R (1999) Anatomie comparée des mammifères domestiques: Ostéologie. Vigot Frères, Paris.

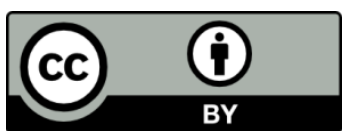

Rios M. Is the Astragalar Index A Valid Character for the Study of Giraffid Phylogeny? Int J 